\title{
May the flexural strength of ceramics be influenced by salivary $\mathrm{pH}$ ?
}

A resistência à flexão de cerâmicas pode ser influenciada pelo pH salivar?

Caroline COTES ${ }^{1}$; Vanessa Cruz MACEDO ${ }^{1}$; Mariana Andrade CAMILLO ${ }^{1}$; Bruna Pastro de LARA ${ }^{1}$; Rodrigo Furtado de CARVALHO ${ }^{1}$; Carolina da Silva Machado MARTINELLI ${ }^{1}$; Estevão Tomomitsu KIMPARA ${ }^{1}$

1 - UNESP - Univ Estadual Paulista - School of Dentistry - Department of Dental Materials and Prosthodontics - São José dos Campos SP - Brazil.

\begin{abstract}
Objective: This study purpose was to compare the three-point flexural strength of feldspathic ceramic after storage in artificial saliva for 30 days with different $\mathrm{pH}$ regimens, as acidic $\mathrm{pH}$ (3.5), neutral $\mathrm{pH}$ (7.0), basic $\mathrm{pH}$ (10) and alternating between acid/ basic $\mathrm{pH}$, for 15 days each. Material and Methods: The bars were luted with resin cement and subjected to storage in artificial saliva of different $\mathrm{pH}$ values. Results: The values of flexural strength were significantly higher for bars stored in distilled water, at neutral and basic $\mathrm{pH}$, when compared with the results for bars stored in acidic $\mathrm{pH}$ and in acid/basic $\mathrm{pH}$. Conclusions: Storage for 30 days in artificial saliva at acidic $\mathrm{pH}$, or alternating between acidic and basic $\mathrm{pH}$, can reduce the mechanical properties of ceramics.
\end{abstract}

\section{KEYWORDS}

Dental porcelain; Artificial saliva; Compressive strength.

\section{RESUMO}

Objetivo: O objetivo do estudo foi comparar a resistência à flexão três pontos de uma cerâmica feldspática após armazenagem em saliva artificial, durante 30 dias com diferentes regimes de $\mathrm{pH}$ : $\mathrm{pH}$ ácido $(3,5), \mathrm{pH}$ neutro $(7,0), \mathrm{pH}$ básico $(10)$ e alternando entre $\mathrm{pH}$ ácido/básico durante 15 dias cada. Material e Métodos: As barras foram cimentados com cimento resinoso e submetidas a armazenagem em saliva artificial com os diferentes valores de $\mathrm{pH}$. Resultados: Os valores de resistência à flexão foram significativamente maiores para as barras armazenadas em água destilada, em $\mathrm{pH}$ neutro e em básico, quando comparadas com os resultados para as barras armazenadas em pH ácido e em meio ácido/básico. Conclusões: A armazenamento durante 30 dias em saliva artificial, com $\mathrm{pH}$ ácido, ou alternando entre $\mathrm{pH}$ ácido e basico, pode reduzir as propriedades mecânicas das cerâmicas.

\section{PALAVRAS-CHAVE}

Porcelana dental; Saliva artificial; Força de compressão.

\section{INTRODUCTION}

C eramics are widely used in dentistry because of their excellent properties. Chemical durability is one of the requirements for their intra-oral use, since dental prostheses must be resistant to degradation in a wide range of variable $\mathrm{pH}$ solutions. Although ceramics are considered to be the most inert of all dental materials used for restorations[1], in reality, some ceramics are not chemically inert, even in a neutral aqueous environment[2], and storage in acid or basic $\mathrm{pH}$ can result in degradation of their flexural strength $[1,3]$.

However, few studies have been performed to measure the effects of chemical 'attack' on ceramics over the entire $\mathrm{pH}$ range[1], and no study has evaluated the effects of $\mathrm{pH}$ changes on their mechanical properties. Therefore, the aim of this study was to evaluate the flexural strength of a feldspathic ceramic stored at different pHs. 


\section{MATERIALS AND METHODS}

Fifty bars (20 mm x $2 \mathrm{~mm} \times 2 \mathrm{~mm}$ ) of ceramic (VITA VM7, VITA Zahnfabrik, Bad Säckingen, Germany) were fabricated according to the manufacturer's instructions. The bars were etched with $10 \%$ hydrofluoric acid for 20 s, washed, and dried. The silane (RelyX Ceramic Primer, 3M-ESPE, Seefeld, Germany) was applied to the etched surface, and after $60 \mathrm{~s}$ an air-spray was applied for $5 \mathrm{~s}$. The luting agent (RelyX ARC, 3M-ESPE, Seefeld, Germany) was manipulated according to the manufacturer's instructions and applied to the treated surface. A load of $750 \mathrm{~g}$ was applied to standardize the luting layer, and the specimens were light-cured for $40 \mathrm{~s}$ on each side. Specimens were stored for 30 days in artificial saliva (except for control), at $37^{\circ} \mathrm{C}$, and the solutions were changed each 5 days. The bars were divided into 5 groups $(\mathrm{n}=10)$ according to storage regimen:

Group 1(C): control, distilled water

Group 2(A): acidic pH (3.5) artificial saliva

Group 3(N): neutral pH (7.0) artificial saliva

Group 4(B): basic pH (10) artificial saliva

Group 5(A/B): alternating between acid/basic $\mathrm{pH}$ artificial saliva, for 15 days each.

The three-point flexural strength test was performed in $37^{\circ} \mathrm{C}$ distilled water, and the flexural strength values (MPa) were subjected to one-way ANOVA and Tukey's test.

\section{RESULTS}

The results of the one-way ANOVA test showed statistically significant differences among the groups $(p$-value $=0.000)$ (see the Table 1$)$.

Table 1 - Mean and standard deviation values the groups, and results of Tukey's test

\begin{tabular}{c|c|c}
\hline Groups & $\begin{array}{c}\text { Means and standard } \\
\text { deviations(MPa) }\end{array}$ & Tukey's test* \\
\hline C & $95.63 \pm 12.45$ & $\mathrm{~A}$ \\
\hline A & $61.27 \pm 14.35$ & $\mathrm{~B}$ \\
\hline N & $87.71 \pm 14.70$ & $\mathrm{~A}$ \\
\hline B & $89.16 \pm 16.74$ & $\mathrm{~A}$ \\
\hline A/B & $62.71 \pm 18.80$ & $\mathrm{~B}$ \\
\hline
\end{tabular}

*Different letters show statistically significant differences.

\section{DISCUSSION}

The mechanical properties of feldspathic ceramics were affected by storage in acidic artificial saliva for 30 days and 15 days with alternation. Shorter storage in acid $\mathrm{pH}$ did not cause surface changes [4], but after 7 days of acid immersion, surface deterioration could be observed[1,2], with numerous porosities and small cracks covering the feldspathic ceramic surface[2]. This surface alteration could reduce the ceramic's flexural strength, although the crack growth rates of existing flaws were similar over time, regardless of the salivary $\mathrm{pH}$ [3]. Furthermore, the hardness of feldspathic ceramic could decrease with an increase in the $\mathrm{pH}$ [3], but this might not be responsible for the decrease in flexural strength, since storage in basic and neutral $\mathrm{pH}$ showed no influence on the present data. It was observed that the acid $\mathrm{pH}$ was more detrimental to flexural strength, even when alternating acidic and basic storage media.

The use of luting agent before the storage is justified for standardization of tensile surface in tensile test and for simulation of ceramic clinical use. The combination of surface pretreatment and luting switches the fracture origin from the porcelain/cement interface to cement surface, similar of what occurs clinically [5].

The observations from this study indicate that dietary habits including ingestion of highly acidic foods, like citric fruits, might result in lowered mechanical strength of ceramic restorations over the long term. Exposure of ceramics to gastric acid could also be harmful to their properties [4], but this effect may be reduced by dilution and through the action of buffering systems [2]. It should be taken into account that this study had limitations, since the conditions in which the samples were stored were not identical to those found in the oral cavity, which presents a more complex environment [2], such as more rapid temperature changes, masticatory stress, daily brushing, and $\mathrm{pH}$ changes for each food ingested, as well as for acidic by-products released by bacteria. However, clinicians should be aware that ceramics could have decreased resistance in patients who ingest acidic foods or have bulimia. 


\section{CONCLUSION}

The flexural strength of feldspathic ceramic stored in acid or acid/basic $\mathrm{pH}$ might be decreased in comparison with that of ceramics stored in basic and neutral $\mathrm{pH}$ artificial saliva, or in distilled water.

\section{REFERENCES}

1. Anusavice KJ. Degradability of dental ceramics. Adv Dent Res. 1992 Sep;6:82-9.
2. Kukiattrakoon B, Hengtrakool C, Kedjarune-Leggat U. The effect of acidic agents on surface ion leaching and surface characteristics of dental porcelains. J Prosthet Dent. 2010 Mar;103(3):148-62.

3. Pinto MM, Cesar PF, Rosa V, Yoshimura HN. Influence of $\mathrm{pH}$ on slow crack growth of dental porcelains. Dent Mater. 2008 Jun;24(6):81423.

4. Matsou E, Vouroutzis N, Kontonasaki E, Paraskevopoulos KM, Koidis P. Investigation of the influence of gastric acid on the surface roughness of ceramic materials of metal-ceramic restorations. An in vitro study. Int J Prosthodont. 2011 JanFeb;24(1):26-9.

5. Fleming GJ, Maguire FR, Bhamra G, Burke FM, Marquis PM. The strengthening mechanism of resin cements on porcelain surfaces. J Dent Res. 2006 Mar;85(3):272-6.

\section{Vanessa Cruz Macedo \\ (Correspondig author)}

Av. Eng Francisco José Longo 777

Jd. São Dimas - São José dos Campos

Received: 2013 Jun 03

12245-000 - São Paulo - SP - Brazil

Accepted: 2013 Jun 24 